\title{
Clinical restenosis and its predictors after implantation of everolimus-eluting bioresorbable vascular scaffolds: results from GABI-R
}

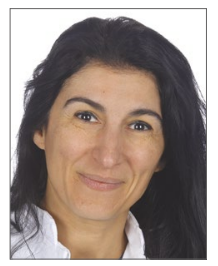

Julinda Mehilli1 ${ }^{1,2 *}$, MD; Stephan Achenbach³ ${ }^{3}$ MD; Jochen Wöhrle ${ }^{4}$, MD; Morritz Baquet ${ }^{1}$, MD; Thomas Riemer ${ }^{5}, \mathrm{PhD}$; Thomas Münzel ${ }^{6,7}$, MD; Holger M. Nef ${ }^{8}, \mathrm{MD}$; Christoph Naber ${ }^{9}, \mathrm{MD}$; Gert Richardt ${ }^{10}$, MD; Ralf Zahn ${ }^{11}$, MD; Tommaso Gori ${ }^{6,7}$, MD; Till Neumann ${ }^{12}$, MD, PhD; Johannes Kastner ${ }^{13}$, MD; Axel Schmermund ${ }^{14}$, MD; Christian Hamm, ${ }^{8,15}$, MD; for the GABI-R Study Group

\begin{abstract}
1. Department of Cardiology, Munich University Clinic, LMU, Munich, Germany; 2. German Centre for Cardiovascular Research, partner site Munich Heart Alliance, Munich, Germany; 3. Department of Cardiology, Friedrich-Alexander University Erlangen-Nürnberg, Erlangen, Germany; 4. Department of Internal Medicine II, University of Ulm, Ulm, Germany; 5. IHF GmbH - Institut für Herzinfarktforschung, Ludwigshafen, Germany; 6. Zentrum für Kardiologie, University Medical Center, Johannes Gutenberg University Mainz, Mainz, Germany; 7. German Centre for Cardiovascular Research, partner site Rhine Main, Mainz, Germany; 8. Medizinische Klinik I, Department of Cardiology, University of Giessen, Giessen, Germany; 9. Klinik für Kardiologie und Angiologie, Elisabeth-Krankenhaus, Essen, Germany; 10. Herzzentrum, Segeberger Kliniken GmbH, Bad Segeberg, Germany; 11. Abteilung für Kardiologie, Herzzentrum Ludwigshafen, Ludwigshafen, Germany; 12. Department of Cardiology, University of Essen, Essen, Germany; 13. Department of Cardiology, University of Vienna Medical School, Vienna, Austria; 14. Bethanien Hospital, Frankfurt, Germany; 15. Department of Cardiology, Kerckhoff Heart and Thorax Center, Bad Nauheim, Germany
\end{abstract}

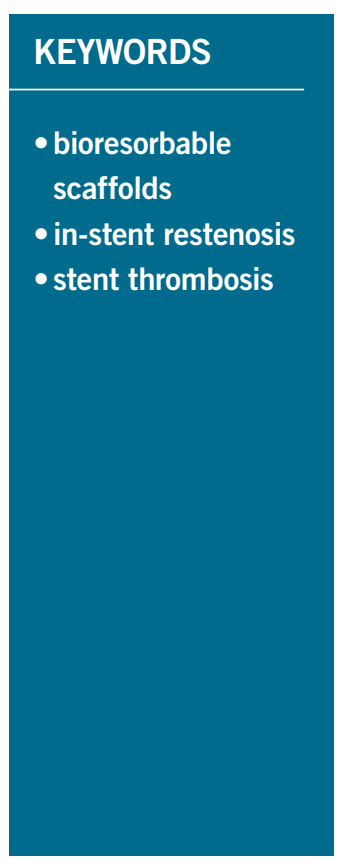

\begin{abstract}
Aims: The aim of this study was to assess clinical restenosis and its predictors after implantation of bioresorbable vascular scaffolds (BVS) in everyday practice in the large-scale German-Austrian ABSORB Registry (GABI-R).

Methods and results: Between November 2013 and January 2016, 3,264 patients underwent BVS implantation in the 93 centres of GABI-R (ClinicalTrials.gov NCT02066623). At six-month follow-up, 24 patients experienced clinically indicated target lesion revascularisation (cTLR) unrelated to BVS thrombosis (cumulative incidence $0.76 \%$; angiographically, $58.3 \%$ of in-BVS restenosis of focal pattern). Compared to patients without cTLR, patients with cTLR had more lesions per patient ( $1.83 \pm 1.0$ vs. $1.36 \pm 0.7)$, complex $(52.3 \%$ vs. $36.2 \%)$ and mild-to-moderately calcified lesions $(65.9 \%$ vs. $60.5 \%)$ treated, and more frequently had overlapping BVS (22.2\% vs. $10.8 \%)$, all $\mathrm{p}<0.05$. Implanted BVS length was $40.0 \mathrm{~mm}(28.0,46.9)$ vs. $23.0 \mathrm{~mm}(18.0,30.0), \mathrm{p}<0.001$, remaining in the multivariable analysis the only independent predictor of cTLR (hazard ratio 1.02, 95\% CI: 1.01-1.04, $\mathrm{p}<0.001$ ). The myocardial infarction rate was also significantly higher among patients with cTLR, $29.2 \%$ vs. $1.7 \%$, p $<0.0001$.
\end{abstract}

Conclusions: cTLR related to BVS restenosis at six months after BVS implantation is a rare event depending on implanted BVS length. Whether cTLR increases the myocardial infarction risk needs to be evaluated at longer-term follow-up and within the setting of adequately powered randomised trials.

\footnotetext{
*Corresponding author: Department of Cardiology, Munich University Clinic, Marchioninistr. 15, 81377 Munich, Germany. E-mail: Julinda.Mehilli@med.uni-muenchen.de
} 


\section{Abbreviations}

$\begin{array}{ll}\text { BVS } & \text { bioresorbable vascular scaffold } \\ \text { CI } & \text { confidence interval } \\ \text { CTLR } & \text { clinically indicated target lesion revascularisation } \\ \text { DES } & \text { drug-eluting stents } \\ \text { HR } & \text { hazard ratio } \\ \text { MI } & \text { myocardial infarction } \\ \text { PCI } & \text { percutaneous coronary intervention } \\ \text { SD } & \text { standard deviation }\end{array}$

\section{Introduction}

Restenosis with the need for repeat revascularisation, although infrequent, continues to represent a clinical risk during long-term follow-up after implantation of drug-eluting stents (DES) ${ }^{1}$. Therefore, stent technologies, which allow temporary scaffolding of the vessel while providing a device-free coronary tree at longer term, are an attractive concept. Of the currently available fully bioresorbable drug-eluting platforms, the Absorb ${ }^{\mathrm{TM}}$ (Abbott Vascular, Santa Clara, CA, USA) scaffold - a polylactic acid-based bioresorbable vascular scaffold (BVS) is the most frequently used and the most extensively clinically tested device. After the first studies reported very promising data at short- and long-term follow-up, a series of randomised studies was started ${ }^{2-7}$. Available results indicate a risk of scaffold thrombosis which is higher than for DES, and which seems to be strongly dependent on lesion selection and implantation technique $^{8-10}$. On the other hand, the reported incidences of clinically indicated target lesion revascularisation (cTLR) were comparabale between BVS and modern everolimus-eluting stents ${ }^{3,6}$. Several anatomical and procedural factors such as calcified and ostial lesions, small vessel size, lack of adequate lesion preparation or BVS overlapping have been identified as increasing this risk ${ }^{8,11}$. These findings have led to a more rigorous selection of lesions considered for BVS implantation and to the use of a strictly standardised implantation procedure. To monitor the clinical usage and performance of BVS in everyday practice, the German-Austrian ABSORB Registry (GABI-R) was designed - a prospective registry enrolling consecutive patients undergoing BVS implantation at 93 centres in two countries ${ }^{12}$. The large number of prospectively included patients and detailed characterisation of the population in this registry allow the assessment of adverse events and their predictive factors. In the current analysis we aimed to assess the incidence of clinical restenosis and its predictors within six months after BVS implantation.

\section{Editorial, see page 1259}

\section{Methods}

Between November 2013 and January 2016, 3,264 patients underwent implantation of the latest version of the BVS (Absorb BVS) in the 93 GABI-R centres. As published previously ${ }^{12}$, GABI-R is an observational study and patient participation in this registry has no impact on further management. BVS use was left to the operators' discretion. The recommended BVS implantation procedure followed most recent standards and has been been published previously ${ }^{13}$. The extent of lesion preparation and use of intracoronary imaging (for BVS sizing reasons) was left to the individual operator's discretion. Antiplatelet therapy consisted of aspirin and a $\mathrm{P} 2 \mathrm{Y}_{12}$ receptor inhibitor for at least 12 months.

The study was conducted in accordance with the provisions of the Declaration of Helsinki. The ethics committees of the participating institutions approved the registry protocol. All patients provided written, informed consent.

\section{DATA MANAGEMENT, DEFINITIONS AND OUTCOME OF INTEREST}

Data within GABI-R are collected electronically via an internet-based application and centralised at the Institut für Herzinfarktforschung (IHF GmbH, Ludwigshafen, Germany). All events were adjudicated and classified by an independent events adjudication committee.

The incidence of clinical restenosis and identification of its predictors are the outcomes of interest of the current analysis. Clinical restenosis was defined as clinically indicated percutaneous or surgical TLR not related to BVS thrombosis. Scaffold thrombosis was defined as definite or probable according to Academic Research Consortium (ARC) criteria. Cardiac death was defined as death from immediate cardiac cause or complications related to the procedure as well as any death in which a cardiac cause could not be excluded. Myocardial infarction (MI) was defined according to the World Health Organization extended definition ${ }^{3}$. Target lesion failure (TLF) was defined as a composite of cardiac death, target vessel MI, and cTLR. Target vessel failure (TVF) was defined as a composite of cardiac death, target vessel MI, and clinically indicated target vessel revascularisation (TVR).

\section{STATISTICAL ANALYSIS}

Distributions of metric variables within the two groups, with and without cTLR, are described by means \pm standard deviations or median (quartiles). Binary variables are described by absolute frequencies and percentages. Frequencies of outcomes are complemented by odds ratios and their $95 \%$ confidence limits, where possible. All descriptive statistics are based purely on known (non-missing) values. To explain the incidence of in-BVS restenosis by baseline and procedural variables, a multiple proportional hazards (Cox) regression model was built. Missing values were imputed either by random drawing from the standardised empirical distribution (in case of missing times-to-event), by modal values (binary) or by median values (metrical variables). Predictor variables in the model were pre-specified initially and reduced after assessing the results of a preliminary model. A two-tailed p-value $<0.05$ was considered to indicate statistical significance. Statistical analysis was performed using SAS software, version 9.3 (SAS Institute Inc., Cary, NC, USA).

\section{Results}

\section{PATIENT AND PROCEDURAL CHARACTERISTICS}

At six-month follow-up, of the 3,264 BVS-treated patients enrolled, 86 patients $(2.6 \%)$ had unknown vital status (mean follow-up $49 \pm 2$ days) and 32 patients (1.0\%) had unknown clinical 
status. Of the total cohort of 3,146 patients eligible for the current analysis, 24 patients (cumulative incidence $0.76 \%$ ) (Figure 1) experienced cTLR. Both patient groups - with or without cTLR were comparable regarding their baseline profile (Table 1).

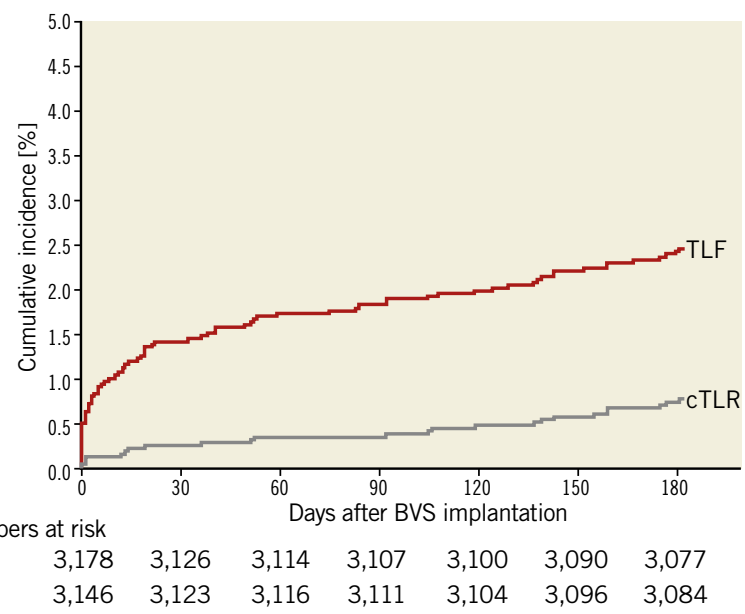

Figure 1. Clinically indicated target lesion revascularisation and target lesion failure at six-month follow-up after BVS implantation. BVS: bioresorbable vascular scaffold; cTLR: clinically indicated target lesion revascularisation; TLF: target lesion failure

Table 1. Baseline clinical characteristics.

\begin{tabular}{|c|c|c|c|}
\hline & With cTLR & Without cTLR & $p$-value \\
\hline Age, yrs & $63.4 \pm 9.9$ & $60.9 \pm 11.0$ & 0.29 \\
\hline Women & $25.0(6 / 24)$ & $23.1(720 / 3,122)$ & 0.82 \\
\hline Diabetes & $27.3(6 / 22)$ & $21.1(652 / 3,097)$ & 0.48 \\
\hline Current smoker & $18.2(4 / 22)$ & $35.1(1,039 / 2,959)$ & 0.10 \\
\hline Hypertension & $66.7(16 / 24)$ & $73.2(2,254 / 3,079)$ & 0.47 \\
\hline $\begin{array}{l}\text { Hypercholesterolae- } \\
\text { mia }\end{array}$ & $66.7(16 / 24)$ & $56.3(1,681 / 2,985)$ & 0.31 \\
\hline $\begin{array}{l}\text { Chronic kidney } \\
\text { disease }\end{array}$ & $4.2(1 / 24)$ & $8.0(247 / 3,098)$ & 0.49 \\
\hline $\begin{array}{l}\text { History of myocardial } \\
\text { infarction }\end{array}$ & $29.2(7 / 24)$ & $22.2(683 / 3,073)$ & 0.42 \\
\hline History of $\mathrm{PCl}$ & $25.0(6 / 24)$ & $27.8(852 / 3,069)$ & 0.76 \\
\hline $\begin{array}{l}\text { History of aorto- } \\
\text { coronary bypass } \\
\text { surgery }\end{array}$ & $0.0(0 / 24)$ & $2.4(76 / 3,109)$ & 0.44 \\
\hline History of stroke & $4.2(1 / 24)$ & $2.7(84 / 3,121)$ & 0.66 \\
\hline $\begin{array}{l}\text { Acute coronary } \\
\text { syndrome at } \\
\text { presentation }\end{array}$ & $33.3(8 / 24)$ & $51.8(1,616 / 3,121)$ & 0.07 \\
\hline $\begin{array}{l}\text { Stable angina } \\
\text { pectoris }\end{array}$ & $37.5(9 / 24)$ & $33.2(1,037 / 3,121)$ & 0.66 \\
\hline $\begin{array}{l}\text { Left ventricular } \\
\text { ejection fraction }\end{array}$ & $53.6 \pm 9.5$ & $56.1 \pm 10.5$ & 0.30 \\
\hline \multicolumn{4}{|l|}{ Severity of CAD } \\
\hline Single-vessel CAD & $33.3(8 / 24)$ & $42.0(1,312 / 3,122)$ & 0.39 \\
\hline Two-vessel CAD & $37.5(9 / 24)$ & $30.9(964 / 3,122)$ & 0.48 \\
\hline Three-vessel CAD & $29.2(7 / 24)$ & $27.1(845 / 3,122)$ & 0.82 \\
\hline
\end{tabular}

Values are mean \pm SD or $\%$ (absolute number/number of available records). CAD: coronary artery disease; cTLR: clinically indicated target lesion revascularisation; $\mathrm{PCl}$ : percutaneous coronary intervention
Compared to patients without cTLR, patients with cTLR underwent more complex procedures requiring significantly longer radiation times, had a higher number of treated lesions/patient, and more complex and severely calcified lesions. In addition, they more frequently had overlapping and longer implanted BVS (Table 2). No differences in chronic antiplatelet therapy at admission and at discharge were observed, while a significantly higher proportion of patients with cTLR was on angiotensin receptor blocker and nitrate therapy at six-month follow-up (Table 3).

\section{CLINICAL OUTCOMES}

The mean follow-up period was $212 \pm 21$ days among cTLR patients, and $219 \pm 36$ days in patients without cTLR, $p=0.98$. A total of 38 patients died, all in the substantially larger group of patients without cTLR. Definite scaffold thrombosis occurred in 30 of the 3,122 patients without cTLR (1.0\%) and one patient $(0.4 \%)$ in the cTLR group after re-PCI for BVS restenosis (Table 4). The overall incidence of MI during follow-up was significantly higher among patients with cTLR $(29.0 \%$ vs. $1.7 \%$, $\mathrm{p}<0.001)$. Angiographically, the majority of in-BVS restenosis had a focal pattern, while malapposition was observed among cases with early in-BVS restenosis undergoing optical coherence tomography (Table 5).

For multivariable analysis, next to the factors that significantly differed between the two groups, traditional predictors of restenosis were forced into the model. Except total implanted BVS length (per each mm increase, hazard ratio [HR] 1.02, 95\% CI: 1.01 $1.04, \mathrm{p}<0.001$ ), none of the other factors (calcified lesion, HR 0.41 [0.12-1.41], $\mathrm{p}=0.16$; complex lesion, HR 0.90 [0.38-2.12], $\mathrm{p}=0.81$; implanted BVS size, HR 0.79 [0.23-2.73], $\mathrm{p}=0.71$; diabetes, HR 1.48 [0.58-3.78], $\mathrm{p}=0.41$ ) independently predicted the risk of cTLR after BVS implantation.

\section{Discussion}

GABI-R is the largest investigator-initiated international registry monitoring routine use and outcomes after BVS implantation. In the current analysis of more than 3,000 patients, we found that: i) the incidence of cTLR related to in-BVS restenosis was extremely low at six months after BVS implantation; ii) none of the traditional factors except implanted BVS length independently predicted the risk of clinical in-BVS restenosis; and iii) the majority of angiographic in-BVS restenoses have a focal pattern and inBVS restenoses occurring early after implantation are frequently caused by BVS malapposition.

The ongoing process of restenosis in the very long term after DES implantation and the need for treatment of recalcitrant restenosis created the scientific basis for development of BVS platforms ${ }^{1,14}$. The polylactic acid-based Absorb BVS, the first commercially available BVS being used on a routine basis, has been evaluated in an extensive programme of registries and randomised trials. While the overall performance of the scaffold was found to be good, several trials and meta-analyses have revealed a slightly, but significantly increased risk of scaffold thrombosis 
Table 2. Angiographic and procedural characteristics.

\begin{tabular}{|c|c|c|c|}
\hline & With cTLR & Without cTLR & $p$-value \\
\hline $\begin{array}{l}\text { Procedure duration, } \\
\text { minutes }\end{array}$ & $70.2 \pm 44.0$ & $58.7 \pm 28.8$ & 0.33 \\
\hline $\begin{array}{l}\text { Radiation time, } \\
\text { minutes }\end{array}$ & $15.0 \pm 8.7$ & $11.8 \pm 8.2$ & $<0.05$ \\
\hline $\begin{array}{l}\text { Amount of contrast } \\
\text { medium, ml }\end{array}$ & $194.6 \pm 88.5$ & $174.7 \pm 74.4$ & 0.40 \\
\hline $\begin{array}{l}\text { Treated lesion/ } \\
\text { patient }\end{array}$ & $1.83 \pm 1.0$ & $1.36 \pm 0.7$ & $<0.01$ \\
\hline \multicolumn{4}{|l|}{ Treated vessel } \\
\hline $\begin{array}{l}\text { Left anterior } \\
\text { descending artery }\end{array}$ & $40.9(18 / 44)$ & $45.8(1,942 / 4,239)$ & 0.52 \\
\hline $\begin{array}{l}\text { Left circumflex } \\
\text { artery }\end{array}$ & $22.7(10 / 44)$ & $21.5(912 / 4,239)$ & 0.85 \\
\hline $\begin{array}{l}\text { Right coronary } \\
\text { artery }\end{array}$ & $36.4(16 / 44)$ & $32.1(1,360 / 4,239)$ & 0.55 \\
\hline Venous graft & $0.0(0 / 44)$ & $0.1(3 / 4,239)$ & 0.86 \\
\hline $\begin{array}{l}\text { Complex lesions } \\
\text { (B2/C) }\end{array}$ & $52.3(23 / 44)$ & $36.2(1,532 / 4,231)$ & $<0.05$ \\
\hline De novo lesion & $97.7(43 / 44)$ & $94.2(3,989 / 4,233)$ & 0.32 \\
\hline Ostial lesion & $0.0(0 / 44)$ & $0.9(36 / 4,233)$ & 0.54 \\
\hline Bifurcation lesion & $0.0(0 / 44)$ & $3.0(126 / 4,233)$ & 0.25 \\
\hline \multicolumn{4}{|l|}{ Calcified lesion } \\
\hline None & $31.8(14 / 44)$ & $36.0(1,524 / 4,231)$ & 0.56 \\
\hline Mild & $59.1(26 / 44)$ & $41.9(1,771 / 4,231)$ & $<0.05$ \\
\hline Moderate & $6.8(3 / 44)$ & $18.7(790 / 4,231)$ & $<0.05$ \\
\hline Severe & $2.3(1 / 44)$ & $3.5(146 / 4,231)$ & 0.67 \\
\hline \multicolumn{4}{|c|}{ Coronary artery flow prior to $\mathrm{PCl}$} \\
\hline TIMI 0 & $9.1(4 / 44)$ & $13.4(566 / 4,227)$ & 0.40 \\
\hline TIMI 1 & $0.0(0 / 44)$ & $8.0(337 / 4,227)$ & 0.05 \\
\hline TIMI 2 & $15.9(7 / 44)$ & $15.4(652 / 4,227)$ & 0.93 \\
\hline TIMI 3 & $75.0(33 / 44)$ & $63.2(2,672 / 4,227)$ & 0.11 \\
\hline $\begin{array}{l}\text { Predilatation } \\
\text { performed }\end{array}$ & $100.0(43 / 43)$ & $99.9(3,875 / 3,877)$ & 0.88 \\
\hline $\begin{array}{l}\text { Debulking device } \\
\text { use }\end{array}$ & $9.3(4 / 43)$ & $8.7(338 / 3,877)$ & 0.89 \\
\hline BVS overlapping & $22.2(8 / 36)$ & $10.8(407 / 3,760)$ & $<0.05$ \\
\hline $\begin{array}{l}\text { Implanted BVS } \\
\text { size, mm }\end{array}$ & $3.0 \pm 0.4$ & $3.1 \pm 0.6$ & 0.53 \\
\hline $\begin{array}{l}\text { Total implanted BVS } \\
\text { length, } \mathrm{mm}\end{array}$ & $\begin{array}{c}40.0 \\
(28.0,46.9) \\
\end{array}$ & $23.0(18.0,30.0)$ & $<0.001$ \\
\hline $\begin{array}{l}\text { BVS implantation } \\
\text { pressure, atm }\end{array}$ & $12.7 \pm 2.8$ & $13.5 \pm 2.7$ & 0.12 \\
\hline $\begin{array}{l}\text { Additional DES } \\
\text { implantation }\end{array}$ & $4.5(2 / 44)$ & $2.9(122 / 4,233)$ & 0.51 \\
\hline $\begin{array}{l}\text { Post-dilatation } \\
\text { performed }\end{array}$ & $75.0(33 / 44)$ & $72.2(3,055 / 4,232)$ & 0.68 \\
\hline $\begin{array}{l}\text { Post-dilation balloon } \\
\text { size, } \mathrm{mm}\end{array}$ & $3.2 \pm 0.5$ & $3.3 \pm 0.5$ & 0.69 \\
\hline $\begin{array}{l}\text { Post-dilation balloon } \\
\text { pressure, atm }\end{array}$ & $16.2 \pm 3.8$ & $16.7 \pm 4.1$ & 0.51 \\
\hline Final TIMI 3 flow & $100.0(44 / 44)$ & $98.1(4,146 / 4,228)$ & 0.35 \\
\hline \multicolumn{4}{|c|}{$\begin{array}{l}\text { Values are mean } \pm \text { SD, median (quartiles) or \% (absolute number/number } \\
\text { of available records). BVS: bioresorbable vascular scaffold; } \\
\text { cTLR: clinically indicated target lesion revascularisation; DES: drug- } \\
\text { eluting stent; PCI: percutaneous coronary intervention }\end{array}$} \\
\hline
\end{tabular}

Table 3. Patients' medical treatment.

\begin{tabular}{|c|c|c|c|}
\hline & With cTLR & Without cTLR & $p$-value \\
\hline \multicolumn{4}{|l|}{ At admission } \\
\hline Aspirin & $62.5(15 / 24)$ & $47.9(1,494 / 3,121)$ & 0.15 \\
\hline $\begin{array}{l}\mathrm{P} 2 \mathrm{Y}_{12} \text { receptor } \\
\text { inhibitors }\end{array}$ & $20.8(5 / 24)$ & $19.8(617 / 3,121)$ & 0.90 \\
\hline Clopidogrel & $40.0(2 / 5)$ & $46.2(285 / 617)$ & 0.78 \\
\hline Prasugrel & $40.0(2 / 5)$ & $27.6(170 / 617)$ & 0.54 \\
\hline Ticagrelor & $20.0(1 / 5)$ & $26.3(162 / 617)$ & 0.75 \\
\hline Oral anticoagulants & $8.3(2 / 24)$ & $4.9(154 / 3,121)$ & 0.44 \\
\hline \multicolumn{4}{|l|}{ Peri-interventionally } \\
\hline Aspirin & $33.3(8 / 24)$ & $33.0(1,029 / 3,121)$ & 0.97 \\
\hline Heparin & $95.8(23 / 24)$ & $93.9(2,931 / 3,121)$ & 0.69 \\
\hline Bivalirudin & $0.0(0 / 24)$ & $1.0(30 / 3,121)$ & 0.63 \\
\hline $\begin{array}{l}\text { Glycoprotein IIb/IIla } \\
\text { inhibitor }\end{array}$ & $8.3(2 / 24)$ & $8.1(253 / 3,121)$ & 0.97 \\
\hline $\begin{array}{l}\text { Loading with } \mathrm{P}_{2} \mathrm{Y}_{12} \\
\text { receptor inhibitor }\end{array}$ & $83.3(20 / 24)$ & $65.1(2,028 / 3,117)$ & 0.06 \\
\hline Clopidogrel & $50.0(10 / 20)$ & $47.3(960 / 2,028)$ & 0.81 \\
\hline Prasugrel & $40.0(8 / 20)$ & $33.8(686 / 2,028)$ & 0.56 \\
\hline Ticagrelor & $10.0(2 / 20)$ & $18.5(375 / 2,028)$ & 0.33 \\
\hline \multicolumn{4}{|l|}{ At discharge } \\
\hline $\begin{array}{l}\text { P2Y }{ }_{12} \text { receptor } \\
\text { inhibitors }\end{array}$ & $95.8(23 / 24)$ & $97.7(3,047 / 3,119)$ & 0.55 \\
\hline Clopidogrel & $43.5(10 / 23)$ & $43.9(1,338 / 3,047)$ & 0.97 \\
\hline Prasugrel & $47.8(11 / 23)$ & $34.0(1,037 / 3,047)$ & 0.16 \\
\hline Ticagrelor & $8.7(2 / 23)$ & $22.1(672 / 3,047)$ & 0.12 \\
\hline
\end{tabular}

At 6-month follow-up

\begin{tabular}{|c|c|c|c|}
\hline Aspirin & $95.7(22 / 23)$ & $93.2(2,532 / 2,718)$ & 0.64 \\
\hline $\begin{array}{l}\mathrm{P}_{2 Y_{12}} \text { receptor } \\
\text { inhibitors }\end{array}$ & $91.3(21 / 23)$ & $93.2(2,516 / 2,699)$ & 0.72 \\
\hline Clopidogrel & $42.9(9 / 21)$ & $43.9(1,099 / 2,506)$ & 0.93 \\
\hline Prasugrel & $42.9(9 / 21)$ & $33.3(835 / 2,506)$ & 0.36 \\
\hline Ticagrelor & $14.3(3 / 21)$ & $22.8(572 / 2,506)$ & 0.35 \\
\hline Oral anticoagulants & $20.0(4 / 20)$ & $8.3(219 / 2,623)$ & 0.06 \\
\hline Beta-blocker & $66.7(16 / 24)$ & $64.3(1,992 / 3,100)$ & 0.81 \\
\hline ACE inhibitors & $37.5(9 / 24)$ & $46.4(1,439 / 3,100)$ & 0.38 \\
\hline $\begin{array}{l}\text { Angiotensin } \\
\text { receptor blocker }\end{array}$ & $45.8(11 / 24)$ & $25.5(790 / 3,100)$ & $<0.05$ \\
\hline Nitrates & $8.3(2 / 24)$ & $1.5(47 / 3,100)$ & $<0.01$ \\
\hline Statins & $79.2(19 / 24)$ & $75.1(2,327 / 3,100)$ & 0.64 \\
\hline
\end{tabular}

as compared to thrombosis of metal-based $\mathrm{DES}^{3-7,9,10}$. On the other hand, the necessity for revascularisation due to restenosis seemed to be comparable among BVS and $\mathrm{DES}^{3,6}$. In the Comparison of Everolimus- and Biolimus-Eluting Stent with Everolimus-Eluting Bioresorbable Scaffold Stents (EVERBIO) II trial, the BVS platform was randomly compared with two DES platforms regarding the amount of angiographic late lumen loss at nine-month angiographic follow-up. The incidence of TLR was 10\% after 
Table 4. Clinical outcomes at 6-month follow-up.

\begin{tabular}{|c|c|c|c|c|}
\hline & With cTLR N=24 & Without cTLR N=3,122 & Hazard ratio ( $95 \% \mathrm{CI})$ & $p$-value \\
\hline All-cause death & $0.0(0)$ & $1.2(38)$ & 0.59 & \\
\hline Cardiac & 0.0 & $0.4(12)$ & 0.76 & \\
\hline Cardiovascular & 0.0 & $0.4(12)$ & 0.90 & \\
\hline Non-cardiac & 0.0 & $0.2(7)$ & 0.82 & \\
\hline Unknown origin & 0.0 & $0.2(7)$ & 0.82 & \\
\hline Definite/probable BVS thrombosis & $4.2(1)$ & $1.4(44)$ & $3.04(0.40-23.02)$ & 0.26 \\
\hline Definite & $4.2(1)$ & $1.0(30)$ & $4.48(0.59-34.26)$ & 0.11 \\
\hline Probable & $0.0(0)$ & $0.4(14)$ & & 0.73 \\
\hline Any myocardial infarction & $29.2(7)$ & $1.7(53)$ & $23.84(9.49-59.90)$ & $<0.0001$ \\
\hline Target vessel-related MI & $25.0(6)$ & $1.3(41)$ & $25.05(9.48-66.34)$ & $<0.0001$ \\
\hline Target lesion revascularisation & $100.0(24)$ & $1.0(30)$ & & $<0.0001$ \\
\hline Repeat PCl & $91.7(22)$ & $1.0(30)$ & $273.00(36.8-2,035)$ & $<0.0001$ \\
\hline CABG surgery & $8.3(2)$ & $0.3(10)$ & $28.30(5.86-136.7)$ & $<0.0001$ \\
\hline Any revascularisation & $100.0(24)$ & $8.0(250)$ & & \\
\hline $\mathrm{PCl}$ & $91.7(22)$ & $7.8(242)$ & $273.72(36.81-2,035)$ & $<0.0001$ \\
\hline CABG graft surgery & $8.3(2)$ & $0.3(10)$ & $28.29(5.86-136.67)$ & $<0.0001$ \\
\hline Target lesion failure & $100.0(24)$ & $1.5(48)$ & & $<0.0001$ \\
\hline Target vessel failure & $100.0(24)$ & $2.6(80)$ & & $<0.0001$ \\
\hline
\end{tabular}

BVS implantation and $8 \%$ after DES implantation, $p=0.59$. These findings are supported by the recently published Amsterdam Investigator-initiateD Absorb strategy all-comers (AIDA) randomised trial which was powered for clinical endpoints $(n=1,845)$. The trial required no routine angiographic follow-up and the incidence of cTLR due to restenosis was $2.4 \%$ with Absorb and $2.5 \%$ with DES at one-year follow-up ${ }^{6}$. Compared to randomised trials, much lower rates of TLR unrelated to thrombosis have been reported for real-world cohorts. In the GHOST-EU registry, of the 1,189 enrolled patients, 25 patients required in-BVS revascularisation (cumulative incidence, $2.5 \%)$ due to thrombosis $(n=20)$ or restenosis $(n=5)$ at six-month follow-up ${ }^{4}$. In the current analysis of GABI-R, we also observed a very low rate of cTLR (0.76\%). Lack of routine angiographic follow-up, patient selection and particularly lesion selection play an important role in explaining the very low rate of this complication. In our registry, $23 \%$ of lesions were of complex morphology. The use of BVS in bifurcation lesions and ostial lesions was discouraged and occurred in only $3 \%$ of cases. This is a relevant difference in comparison to the AIDA trial, where $55 \%$ of BVS-treated lesions were of complex and $10 \%$ of ostial or bifurcational morphology ${ }^{6}$. On the other hand, widespread use of appropriate lesion preparation and BVS implantation techniques as encouraged in GABI-R (predilatation in all cases and post-dilatation in approximately $3 / 4$ of all patients) might have contributed to the low cTLR ${ }^{15}$.

Diabetes mellitus, vessel size (device size), stented length, residual stenosis or stent overlap have frequently been identified as predictors of restenosis after percutaneous coronary intervention ${ }^{16}$.
In the current study, only the total length of the implanted BVS was identified as a predictor of cTLR at follow-up. The very selected nature of the population and lesions in the GABI-R, technically more demanding procedures among patients with cTLR leading to additional BVS implantation and BVS size-lesion mismatch might have played a role in these findings. Another explanation might be the type of in-BVS restenosis. Nearly $25 \%$ of cTLR occurred within the first 30 days and were therefore most likely not related to neointimal hyperplasia (intracoronary imaging of some of these cases supports this). The lower radial strength with polylactic acid-based BVS as compared to DES might lead to early restenosis within BVS due to elastic recoil ${ }^{17}$.

Generally, restenosis is considered a benign event being either asymptomatic or with stable clinical presentation. However, in the GABI-R, about one quarter of patients with cTLR presented with target vessel MI compared to only $1.3 \%$ of patients without cTLR ( $1 \%$ due to BVS thrombosis). Long-term follow-up of large registries and randomised trials will be required to corroborate our observations and to investigate further the mechanisms and consequences of in-BVS restenosis.

\section{Limitations}

GABI-R is a prospective clinical registry, which inherently harbours patient selection bias, heterogeneity regarding lesion preparation and PCI technique, as well as a certain degree of incompleteness of data collection. On the other hand, determination of restenosis or thrombosis at the time of revascularisation was based on centrally reviewed angiograms. However, lack of systematic intracoronary 
Table 5. Key clinical and angiographic characteristics of patients with cTLR.

\begin{tabular}{|c|c|c|c|c|c|c|c|c|}
\hline Case & Treated vessel & $\begin{array}{c}\text { Clinical presentation at } \\
\text { CTLR }\end{array}$ & $\begin{array}{l}\text { BVS size/ } \\
\text { length } \mathrm{mm}\end{array}$ & $\begin{array}{l}\text { Angiographic in-BVS } \\
\text { restenosis pattern }\end{array}$ & $\begin{array}{l}\% \\
\text { DS }\end{array}$ & Additional findings & $\begin{array}{l}\text { Type of } \\
\text { cTLR }\end{array}$ & $\begin{array}{l}\text { Days to } \\
\text { CTLR }\end{array}$ \\
\hline 1 & Proximal LCx & SAP & $3.0 / 28$ & Diffuse intra-BVS & 90 & & DES & 105 \\
\hline 2 & Distal LAD & SAP & $2.5 / 18$ & Focal body & 70 & & DEB & 159 \\
\hline 3 & Mid LCx & UAP & $3.0 / 18$ & No restenosis & 30 & $\begin{array}{c}70 \% \text { stenosis of left main } \\
\text { artery }\end{array}$ & $\begin{array}{l}\text { CABG } \\
\text { surgery }\end{array}$ & 13 \\
\hline 4 & Distal RCA & SAP & $\begin{array}{l}3.0 / 18 \\
2.5 / 12\end{array}$ & Diffuse intra-BVS & 60 & & DES & 175 \\
\hline 5 & Mid RCA & SAP & $3.0 / 12$ & Focal body & 90 & & DES & 159 \\
\hline 6 & Mid LAD & UAP & $3.0 / 28$ & Focal body & 70 & OCT: BVS malapposition & POBA & 6 \\
\hline 7 & Mid RCA & NSTEMI & $3.0 / 18$ & Focal margin proximal & 90 & $\begin{array}{l}\text { OCT: BVS malapposition } \\
\text { and residual dissection }\end{array}$ & DES & 2 \\
\hline 8 & Mid RCA & $\begin{array}{c}\text { Exercise-induced ischaemia } \\
\text { (echocardiography) }\end{array}$ & $3.5 / 28$ & Diffuse intra-BVS & 60 & & DES & 51 \\
\hline 9 & Distal LAD & SAP & $2.5 / 28$ & Focal margin distal & 99 & & DES & 181 \\
\hline 10 & Mid LAD & UAP & $\begin{array}{l}3.5 / 18 \\
3.0 / 28\end{array}$ & Multifocal & 70 & $\begin{array}{c}\text { Restenosis also at BVS } \\
\text { overlap }\end{array}$ & DES & 106 \\
\hline 11 & Mid RCA & UAP & $\begin{array}{l}3.0 / 28 \\
3.0 / 28\end{array}$ & Diffuse intra-BVS & 70 & & DES & 92 \\
\hline 12 & Mid LAD & UAP & $\begin{array}{l}2.5 / 12 \\
2.5 / 18\end{array}$ & Focal gap & 90 & $\begin{array}{c}\text { Restenosis within the gap } \\
\text { between } 2 \text { BVS }\end{array}$ & DES & 119 \\
\hline 13 & Distal LAD & $\begin{array}{c}\text { Exercise-induced ischaemia } \\
\text { (myocardial scintigraphy) }\end{array}$ & $3.5 / 18$ & Focal margin distal & 60 & & DES & 52 \\
\hline 14 & Diagonal branch & STEMI & $2.5 / 18$ & Focal margin proximal & 99 & Ostial lesion at index $\mathrm{PCl}$ & DES & 137 \\
\hline 15 & Mid LAD & UAP & $3.5 / 12$ & Diffuse intra-BVS & 50 & $\begin{array}{l}\text { Angiographically no tissue } \\
\text { growth }\end{array}$ & POBA & 14 \\
\hline 16 & Mid LAD & UAP & $2.5 / 28$ & Focal margin distal & 70 & & DES & 80 \\
\hline 17 & Mid RCA & UAP & $3.5 / 18$ & Diffuse intra-BVS & 40 & $\begin{array}{c}\text { Angiographically no tissue } \\
\text { growth }\end{array}$ & DES & 36 \\
\hline 18 & Mid LCx & SAP & $\begin{array}{l}2.5 / 18 \\
2.5 / 12\end{array}$ & Complete occlusion & 100 & & $\begin{array}{l}\text { CABG } \\
\text { surgery }\end{array}$ & 177 \\
\hline 19 & Proximal RCA & $\begin{array}{c}\text { exercise-induced ischaemia } \\
\text { (cycle ergometer) }\end{array}$ & $3.5 / 18$ & Focal body & 75 & & DES & 143 \\
\hline 20 & Proximal RCA & UAP & $3.5 / 23$ & Focal margin proximal & 50 & $\begin{array}{l}\text { Angiographically } \\
\text { tissue prolapse }\end{array}$ & DES & 5 \\
\hline 21 & Mid LAD & NSTEMI & $2.5 / 18$ & Focal margin distal & 90 & & DES & 152 \\
\hline 22 & Mid LCX & NSTEMI & $2.5 / 28$ & Diffuse intra-BVS & 40 & OCT: BVS malapposition & DES & 1 \\
\hline 23 & Distal LAD & UAP & $2.5 / 18$ & Focal margin proximal & 70 & & DES & 139 \\
\hline 24 & Marginal branch & NSTEMI & $3.0 / 28$ & Focal margin proximal & 50 & $\begin{array}{l}\text { OCT: BVS malapposition } \\
\text { at the vessel ostium }\end{array}$ & DES & 19 \\
\hline \multicolumn{9}{|c|}{$\begin{array}{l}\text { BVS: bioresorbable vascular scaffold; CABG: coronary artery bypass grafting; cTLR: clinically indicated target lesion revascularisation; DEB: drug-eluting } \\
\text { balloon; DES: drug-eluting stent; LAD: left anterior descending artery; LCX: left circumflex artery; (N)STEMI: (non) ST-segment elevation myocardial } \\
\text { infarction; OCT: optical coherence tomography; POBA: plain old balloon angioplasty; prox: proximal; RCA: right coronary artery; (U)SAP: (un)stable } \\
\text { angina pectoris }\end{array}$} \\
\hline
\end{tabular}

imaging at the time of cTLR might have hampered the evaluation of the true incidence and aetiology of in-BVS restenosis. Finally, a follow-up duration of six months is probably not sufficient to evaluate the clinical performance of BVS. GABI-R will follow all patients for up to five years after BVS implantation, which will allow a detailed time-dependent characterisation of restenosis after BVS implantation.

\section{Conclusions}

Clinical restenosis at six months after BVS implantation, a rare event, is associated with a greater length of implanted BVS. Whether this is related to a higher risk of myocardial infarction or other hard endpoints needs to be evaluated at longerterm follow-up and within the setting of adequately powered randomised trials. 


\section{Impact on daily practice}

The rate of thrombosis after bioresorbable vascular scaffold implantation is higher than expected, but this may be addressed by meticulous lesion selection and implantation technique. Clinical restenosis is a parameter that characterises treatment success independently from scaffold thrombosis but has been infrequently reported. We demonstrate that clinical restenosis within six months after BVS implantation is an infrequent event and depends on the implanted BVS length. This is encouraging, since it highlights that implantation strategies which achieve low rates of thrombosis will not be offset by high rates of other clinical events. Furthermore, in-BVS restenosis occurring earlier after BVS implantation suggests elastic recoil as one of its possible mechanisms and emphasises that BVS implantation within vessel segments at high mechanical stress should be avoided.

\section{Funding}

The GABI Registry is supported by Abbott Vascular, Santa Clara, CA, USA.

\section{Conflict of interest statement}

J. Mehilli has received lecture fees from and is on the advisory board of Abbott Vascular, Biotronik and Terumo, has received lecture fees from Lilly/Daiichi Sankyo and Boston Scientific, and institutional research grants from Abbott Vascular and Edwards Lifesciences. S. Achenbach has received research grants (institutional) from Abbott Vascular and Siemens Healthcare. H. Nef has received research grants (institutional) and speaker honoraria from Abbott Vascular. G. Richardt is on the advisory board for Abbott Vascular. T. Gori has received lecture fees from Abbott Vascular. A. Schmermund has received a speaker's honorarium from Abbott Vascular. C. Hamm has received a speaker's honorarium from Abbott Vascular. The other authors have no conflicts of interest to declare.

\section{References}

1. Natsuaki M, Morimoto T, Furukawa Y, Nakagawa Y, Kadota K, Yamaji K, Ando K, Shizuta S, Shiomi H, Tada T, Tazaki J, Kato Y, Hayano M, Abe M, Tamura T, Shirotani M, Miki S, Matsuda M, Takahashi M, Ishii K, Tanaka M, Aoyama T, Doi O, Hattori R, Kato M, Suwa S, Takizawa A, Takatsu Y, Shinoda E, Eizawa H, Takeda T, Lee JD, Inoko M, Ogawa H, Hamasaki S, Horie M, Nohara R, Kambara H, Fujiwara H, Mitsudo K, Nobuyoshi M, Kita T, Kimura T; CREDO-Kyoto PCI/CABG registry cohort-2 investigators. Late adverse events after implantation of sirolimus-eluting stent and bare-metal stent: long-term (5-7 years) follow-up of the Coronary Revascularization Demonstrating Outcome study-Kyoto registry Cohort-2. Circ Cardiovasc Interv. 2014;7:168-79.

2. Serruys PW, Chevalier B, Dudek D, Cequier A, Carrié D, Iniguez A, Dominici M, van der Schaaf RJ, Haude M, Wasungu L, Veldhof S, Peng L, Staehr P, Grundeken MJ, Ishibashi Y,
Garcia-Garcia HM, Onuma Y. A bioresorbable everolimus-eluting scaffold versus a metallic everolimus-eluting stent for ischaemic heart disease caused by de-novo native coronary artery lesions (ABSORB II): an interim 1-year analysis of clinical and procedural secondary outcomes from a randomised controlled trial. Lancet. 2015;385:43-54.

3. Puricel S, Arroyo D, Corpataux N, Baeriswyl G, Lehmann S, Kallinikou Z, Muller O, Allard L, Stauffer JC, Togni M, Goy JJ, Cook S. Comparison of everolimus- and biolimus-eluting coronary stents with everolimus-eluting bioresorbable vascular scaffolds. J Am Coll Cardiol. 2015;65:791-801.

4. Capodanno D, Gori T, Nef H, Latib A, Mehilli J, Lesiak M, Caramanno G, Naber C, Di Mario C, Colombo A, Capranzano P, Wiebe J, Araszkiewicz A, Geraci S, Pyxaras S, Mattesini A, Naganuma T, Münzel T, Tamburino C. Percutaneous coronary intervention with everolimus-eluting bioresorbable vascular scaffolds in routine clinical practice: early and midterm outcomes from the European multicentre GHOST-EU registry. EuroIntervention. 2015; 10:1144-53.

5. Ellis SG, Kereiakes DJ, Metzger DC, Caputo RP, Rizik DG, Teirstein PS, Litt MR, Kini A, Kabour A, Marx SO, Popma JJ, McGreevy R, Zhang Z, Simonton C, Stone GW; ABSORB III Investigators. Everolimus-Eluting Bioresorbable Scaffolds for Coronary Artery Disease. N Engl J Med. 2015;373:1905-15.

6. Wykrzykowska JJ, Kraak RP, Hofma SH, van der Schaaf RJ, Arkenbout EK, IJsselmuiden AJ, Elias J, van Dongen IM, Tijssen RYG, Koch KT, Baan J Jr, Vis MM, de Winter RJ, Piek JJ, Tijssen JGP, Henriques JPS; AIDA Investigators. Bioresorbable Scaffolds versus Metallic Stents in Routine PCI. $N$ Engl J Med. 2017;376:2319-28

7. Serruys PW, Chevalier B, Sotomi Y, Cequier A, Carrié D, Piek JJ, Van Boven AJ, Dominici M, Dudek D, McClean D, Helqvist S, Haude M, Reith S, de Sousa Almeida M, Campo G, Iniguez A, Sabaté M, Windecker S, Onuma Y. Comparison of an everolimus-eluting bioresorbable scaffold with an everolimus-eluting metallic stent for the treatment of coronary artery stenosis (ABSORB II): a 3 year, randomised, controlled, single-blind, multicentre clinical trial. Lancet. 2016;388:2479-91.

8. Puricel S, Cuculi F, Weissner M, Schmermund A, Jamshidi P, Nyffenegger T, Binder H, Eggebrecht H, Münzel T, Cook S, Gori T. Bioresorbable Coronary Scaffold Thrombosis: Multicenter Comprehensive Analysis of Clinical Presentation, Mechanisms, and Predictors. J Am Coll Cardiol. 2016;67:921-31.

9. Windecker S, Koskinas KC, Siontis GCM. Bioresorbable Scaffolds Versus Metallic Drug-Eluting Stents: Are We Getting Any Closer to a Paradigm Shift? J Am Coll Cardiol. 2015;66:2310-4.

10. Cassese S, Byrne RA, Ndrepepa G, Kufner S, Wiebe J, Repp J, Schunkert H, Fusaro M, Kimura T, Kastrati A. Everolimuseluting bioresorbable vascular scaffolds versus everolimus-eluting metallic stents: a meta-analysis of randomised controlled trials. Lancet. 2016;387:537-44.

11. Gori T, Wiebe J, Capodanno D, Latib A, Lesiak M, Pyxaras SA, Mehilli J, Caramanno G, Di Mario C, Brugaletta S, 
Weber J, Capranzano P, Sabate M, Mattesini A, Geraci S, Naber CK, Araszkiewicz A, Colombo A, Tamburino C, Nef H, Münzel T. Early and midterm outcomes of bioresorbable vascular scaffolds for ostial coronary lesions: insights from the GHOST-EU registry. EuroIntervention. 2016;12:e550-6.

12. Nef H, Wiebe J, Achenbach S, Münzel T, Naber C, Richardt G, Mehilli J, Wöhrle J, Neumann T, Biermann J, Zahn R, Kastner J, Schmermund A, Pfannebecker T, Schneider S, Limbourg T, Hamm CW. Evaluation of the short- and long-term safety and therapy outcomes of the everolimus-eluting bioresorbable vascular scaffold system in patients with coronary artery stenosis: Rationale and design of the German-Austrian ABSORB RegIstRy (GABI-R). Cardiovasc Revasc Med. 2016;17:34-7.

13. Tamburino C, Latib A, van Geuns RJ, Sabate M, Mehilli J, Gori T, Achenbach S, Alvarez MP, Nef H, Lesiak M, Di Mario C, Colombo A, Naber CK, Caramanno G, Capranzano P, Brugaletta S, Geraci S, Araszkiewicz A, Mattesini A, Pyxaras SA, Rzeszutko L, Depukat R, Diletti R, Boone E, Capodanno D, Dudek D. Contemporary practice and technical aspects in coronary intervention with bioresorbable scaffolds: a European perspective. EuroIntervention. 2015;11:45-52.

14. Mehilli J, Jochheim D. Paclitaxel-Coated Balloon for Recalcitrant In-Drug-Eluting Stent Restenosis. JACC Cardiovasc Interv. 2015;8:1701-3.

15. Miyazaki T, Latib A, Ruparelia N, Kawamoto H, Sato K, Figini F, Colombo A. The use of a scoring balloon for optimal lesion preparation prior to bioresorbable scaffold implantation: a comparison with conventional balloon predilatation. EuroIntervention. 2016;11:e1580-8.

16. Cassese S, Byrne RA, Tada T, Pinieck S, Joner M, Ibrahim T, King LA, Fusaro M, Laugwitz KL, Kastrati A. Incidence and predictors of restenosis after coronary stenting in 10004 patients with surveillance angiography. Heart. 2014;100:153-9.

17. Dalos D, Gangl C, Roth C, Krenn L, Scherzer S, Vertesich M, Lang I, Maurer G, Neunteufl T, Berger R, Delle-Karth G. Mechanical properties of the everolimus-eluting bioresorbable vascular scaffold compared to the metallic everolimus-eluting stent. BMC Cardiovasc Disord. 2016;16:104. 